\title{
TEACHING IN CLOUDS: USING THE G SUITE FOR EDUCATION FOR THE DELIVERY OF TWO ENGLISH FOR ACADEMIC PURPOSES COURSES
}

\author{
Elis Kakoulli Constantinou \\ Cyprus University of Technology \\ Phone: +35725002599, E-Mail: elis.constantinou@cut.ac.cy
}

\begin{abstract}
Being one of the most important and influential advancements in information technology since the emergence of the Internet, cloud computing has invaded the area of English for Specific Purposes (ESP), among other fields, due to its flexibility, availability, practicality and cost effectiveness. In 2006 Google developed its Apps for Education, currently referred to as "G Suite for Education", that provide teachers and students with access to different tools, such as Classroom, Mail, Drive, Calendar, Docs, etc., each serving different educational purposes. This paper reports on a research study conducted at the Cyprus University of Technology Language Centre in Fall 2016, in the context of two blended English for Academic Purposes (EAP) courses for first-year students of the Departments of Agricultural Sciences, Biotechnology and Food Science and Commerce, Finance and Shipping, which are based on social constructivist approaches with elements of connectivism and student-centered teaching methods. The study aimed at eliciting data on the students' views regarding the ease of use of G Suite for Education tools, difficulties encountered during their use, and their efficiency in the teaching and learning process. Data was obtained through an online questionnaire, consisting of Likert scale and open-ended questions, administered to the students at the end of the semester. Findings illustrate that students viewed the use of G Suite for Education tools in their EAP courses very positively, both in terms of ease of use and efficiency in the learning and teaching process, encountering only minor difficulties during their use.
\end{abstract}

Key words: Cloud Computing, EAP, G Suite for Education, Social Constructivism

\section{INTRODUCTION}

The advent of the Internet has had a profound impact on education and on how learners receive and process knowledge. Since technology is inextricably linked with our everyday reality nowadays, teachers are forced to embrace it and integrate it in the teaching process. In her foreword in Blakes' (2013) Brave New Digital Classroom; Technology and Foreign Language Learning, Claire Kramsch notes that if teachers do not accept this reality, they will not only fail to enjoy all the benefits that technology provides, but they will also fail to communicate essentially with their students, whom she characterises as 'wired, networked and computer-savvy' (p. xi). Cloud computing constitutes one of the most promising and well-received technologies that have emerged the last years conquering business and education. Language education has not remained unaffected by this technology trend; thus, more and more educators every year construct 
their courses using cloud technologies, recognising the potential that they encompass. Carrying many qualities and affordances, if deployed appropriately, cloud technologies may provide an excellent environment for social constructivist and connectivist approaches to language learning.

English for Specific Purposes (ESP) is an area, which by definition concentrates mainly on the specific needs of the learners. Despite the fact that technology on its own cannot be considered a panacea, its use in the ESP class is essential, since it allows for exposition to real language related to the learners' area of expertise (Bloch 2013). In such a context, due to its qualities, cloud computing may potentially ensure more authentic exploitation of real-life material, and thus facilitate the meeting of the learning objectives.

\section{THEORETICAL BACKGROUND}

\subsection{Cloud computing}

The definitions of cloud computing in the literature are numerous. According to the National Institute of Standards and Technology (NIST) (Mell and Grance 2009), '[c]loud computing is a model for enabling convenient, on-demand network access to a shared pool of configurable computing resources (e.g., networks, servers, storage, applications, and services) that can be rapidly provisioned and released with minimal management effort or service provider interaction'. The concept of cloud computing originates in the 1960s, and the cloud image was used to conceptualise the idea of the Internet revealing its sophisticated and complex nature.

The essential characteristics of cloud technologies, as described by the NIST, involve on-demand self-service, broad network access, resource pooling, rapid elasticity and measured service. As far as the services that cloud computing provides, these are summarised as three: Cloud Software as a service (SaaS), Cloud Platform as a service (PaaS) and Cloud Infrastructure as a service (IaaS). Software as a service refers to the various software that consumers are capable of using by accessing the cloud through a web browser using different devices, while platform refers to the capability of the consumer to use programming tools and have control over the different applications they use; finally, infrastructure involves the remote delivery through the internet of a full computer infrastructure (e.g. virtual computers, servers, storage devices, etc.).

The various attributes and affordances of cloud technologies, which derive from their characteristics and the services that they offer, are regarded as very beneficial in an educational context.

\subsection{Cloud computing in education}

Cloud computing has huge potential benefits for different organisations and its viability has been expressed many times in literature (Ercan 2010; Sultan 2010; Lakshminarayanan, Kumar, and Raju 2013; González-Martínez et al. 2015). The benefits for education are quite many since, by deploying cloud technologies, educational institutions can concentrate mainly on learning and research instead of dealing with issues pertaining to Information Technology infrastructure. Some of the benefits of cloud computing listed in the literature are cost effectiveness, since access to a vast amount of applications is provided at a very low cost, convenience, practicality, flexibility and high scalability, since applications continue to work effectively even when they are used at a 
large scale by many people. Moreover, cloud computing is easy to use, and the only requirement is a device that has internet access; hence, the technology infrastructure and training needed are minimal.

Nevertheless, some skeptical voices have been also recorded in the literature (Sultan 2010; Dillon, Wu, and Chang 2010) expressing the view that the low cost of such technologies is in fact a camouflage, and that cloud technologies might prove costly in the future. Another concern is the fact that customers have no control over the technologies used, which can change anytime. Reliability issues are also another source of concern, since in the past it has been reported that service providers had left customers without service for some hours. However, the major causes of worry for the skeptics are the issues of security and privacy, which constitute two of the most prominent and controversial matters today in a world where sharing and exchanging information are dominant.

\subsection{G Suite for Education, social constructivism and connectivism}

G Suite for Education (formally known as Google Apps for Education), the cloud computing services by Google, is a suite of free productivity tools for classroom collaboration (Google n.d.). To become eligible for using the suite, educational organisations should set up a Google institutional account first, which will have administrative responsibilities, e.g. creation of usernames and passwords for all users (teaching staff, administrative staff and students).

Some of the core tools offered by Google and the services each tool provides are listed in Table 1.

Table 1 Core tools provided by Google

\begin{tabular}{ll}
\hline Tools & Services they provide \\
\hline Google Classroom & $\begin{array}{l}\text { Platform on which materials and assignments can be } \\
\text { organised. It offers communication between learners and } \\
\text { teachers and between learners themselves. Teachers can grade } \\
\text { assignments and return them to the students with feedback. }\end{array}$ \\
\hline Gmail & Email service \\
\hline Google Drive & $\begin{array}{l}\text { Storage service that allows users to save all their files, photos } \\
\text { and videos on a cloud and access them on any device, as long } \\
\text { as it is connected to the Internet. It allows users to create } \\
\text { material (e.g. Google Docs, Google Slides, Google Sheets, } \\
\text { etc.), save them on the cloud and share them with other people. } \\
\text { One of its most useful features is the opportunity that it offers } \\
\text { to users to work on the same material simultaneously allowing } \\
\text { for collaboration and communication. }\end{array}$ \\
\hline Google Calendar & $\begin{array}{l}\text { Time-management and scheduling calendar service that allows } \\
\text { users to keep track of all their events. }\end{array}$ \\
\hline Vault & $\begin{array}{l}\text { Tool that lets users retain, hold, search, and export data and it } \\
\text { is mainly used for archiving purposes. }\end{array}$ \\
\hline Google Forms & Tool that creates online surveys and quizzes. \\
\hline Google sites & $\begin{array}{l}\text { Website creation tool that allows users to create sites which } \\
\text { they can use with their classes. }\end{array}$ \\
\hline Hangouts & Tool that helps users connect using voice, video or text. \\
\hline
\end{tabular}


Apart from these core products offered, there is a large amount of other products and applications that are accessible through the suite. These extra applications serve different educational purposes and can be accessed via a Google account. Additionally, they work well on different devices (phones, tablets, laptops), hence a BYOD (Bring Your Own Device) scheme can be implemented, in case the classroom lacks the necessary equipment.

Due to its extreme flexibility, creativity and the fact that it allows for collaboration and synchronous and asynchronous communication, the suite can cater perfectly for any class which is governed by social constructivism (Vygotsky 1978), and/ or connectivism (Siemens 2005). According to Roberts (1998), social constructivist approaches assert that learners construct their knowledge through interaction with the social context. Some of the most prominent practices of a constructivist approach to teaching and learning are active engagement, inquiry, problem solving, and collaboration. Rather than being the only carrier of knowledge, the teacher is a guide, facilitator, and co-explorer, while learners are at the centre of the learning process. They are encouraged to question, challenge, and frame their own ideas. For connectivism, 'knowledge is actuated through the process of a learner connecting to and feeding information into a learning community' (Kop and Hill 2008, 1). This approach to learning focuses on networking and understanding of where to find knowledge. Through $G$ Suite for Education, students can communicate both synchronously and asynchronously (using the Google Classroom comment feature or Hangouts or the Chat feature), collaborate on problem-solving tasks that will eventually push them to produce language (Yilmaz 2011) (e.g. through creating and sharing Google docs or Google Slides), and generally be engaged in the use of language with meaningful social interaction. Moreover, Google classroom creates a feeling of community/ network (Fenton 2017). Hence, the suite can build a web-based environment that favours social constructivist and connectivist approaches to education in general and language education in particular. Taking into account that such approaches are considered to be effective and that they promote learning, since language acquisition involves communication and social interaction (Esteban and Martínez 2014), it can be inferred that G Suite for Education can create the necessary opportunities to enhance language learning.

The fact that the suite supports social constructivist approaches to learning and that it is considered to be efficient in the acquisition of languages is reported in research. Liu and Lan (2016) report on their research study which focused on the differences in motivation, vocabulary gain and perceptions of using Google Docs between individual and collaborative learning in tertiary education. The results showed that the students who collaborated had better vocabulary gain than the ones who worked individually, because of negotiated interaction. Additionally, collaborators were more motivated and had lower levels of test anxiety and more positive perceptions on the use of Google Docs. In their literature review, Liu and Lan (2016) also reported on similar studies, which showed that web-based collaboration led to the creation of positive perceptions and feelings of community-belonging (Kessler, Bikowski, and Boggs 2012; Kennedy and Miceli 2013) and strengthened students' motivation minimising feelings of anxiety (Warschauer 1996).

\section{THE RESEARCH StUdy}

\subsection{The context}

This research study investigated the integration of the G Suite for Education in two ESP courses, more specifically two blended English for Academic Purposes (EAP) 
courses for first-year students of the Departments of Agricultural Sciences, Biotechnology and Food Science (DASBFS) and Commerce, Finance and Shipping (DCFS) at the Cyprus University of Technology Language Centre (CUT LC) in Fall 2016. The general objective of these courses was to enable students to communicate competently at B1-B2 level of the Common European Framework of Reference (CEFR) for Languages on issues related to students' social and student life as well as on issues related to their future professional careers. The courses were based on the theory of social constructivism with some elements of connectivism and student-centered teaching methods; such methods were applied in other research studies conducted in the ESP field as well (Esteban and Martinez 2014). The courses developed both language and transferable 21 st century skills, such as communication, the use of new information and communication technologies (ICT), collaboration, creativity, innovation, critical thinking, intercultural awareness as well as autonomy and lifelong learning.

In order to gain access to the applications offered by Google, the CUT LC created a Google institutional account through which credentials were created for the course instructor (who was also the researcher) and her students. For the delivery of the two EAP courses, two Google Classrooms were created, which served as platforms on which material, assignments, and announcements were uploaded. Moreover, students had the opportunity to take part in online discussions, which were enacted through the "Question" feature on the platform. Google Classroom was also used for the submission of assignments, marking and provision of feedback. The two Google Classrooms created for the two Departments (DASBFS and DCFS) were connected to Google Drive folders that were automatically created, in which everything was stored. Apart from storage purposes, Google Drive was also used for the creation of Google Docs and Google Slides which the students shared and worked on collaboratively.

The tasks in which students were engaged mainly involved collaboration, problemsolving, debating controversial issues, producing artifacts, etc. Some indicative examples of tasks that students were engaged in are presented in Table 2.

Table 2 Examples of social constructivist tasks through G Suite for Education

\begin{tabular}{|c|c|c|}
\hline Examples of Tasks & Tools & Objectives \\
\hline $\begin{array}{l}\text { Introducing themselves to the class } \\
\text { (DASBFS and DCFS) }\end{array}$ & $\begin{array}{r}\text { - Google Classroom } \\
\text { (comment feature) }\end{array}$ & $\begin{array}{l}\text { Breaking the ice/ Getting } \\
\text { familiar with each other }\end{array}$ \\
\hline $\begin{array}{l}\text { Reading an article on Learning Styles, } \\
\text { collaborating in groups to understand } \\
\text { the meaning, writing the most important } \\
\text { points, finding their partners learning } \\
\text { styles, and working together to suggest } \\
\text { techniques that can help them learn best } \\
\text { (DASBFS and DCFS) }\end{array}$ & $\begin{array}{l}\text { - Google Classroom } \\
\text { - Google Drive } \\
\text { - Google docs }\end{array}$ & $\begin{array}{l}\text { Getting familiarised with the } \\
\text { language used to talk about } \\
\text { learning. } \\
\text { Learning about learning and } \\
\text { how to learn best. }\end{array}$ \\
\hline $\begin{array}{l}\text { Studying the safety problem that a } \\
\text { company faces and noting down the } \\
\text { benefits and disadvantages of possible } \\
\text { solutions as a team. Compiling an email } \\
\text { with the best solution to the problem. } \\
\text { (DCFS) }\end{array}$ & $\begin{array}{l}\text { - Google Classroom } \\
\text { - Google Drive } \\
\text { - Google docs }\end{array}$ & $\begin{array}{l}\text { Getting familiarised with the } \\
\text { language used to talk about } \\
\text { safety at work } \\
\text { Learning how to construct } \\
\text { arguments } \\
\text { Learning how to write emails }\end{array}$ \\
\hline
\end{tabular}




\subsection{The purpose and methodology of the study}

The study was an action research study the purpose of which was to evaluate the use of $\mathrm{G}$ Suite for Education in the delivery of two blended EAP courses at the Cyprus University of Technology in an effort to find a solution to a problem: the lack of appropriate tools which ensure classroom management, saving, organising and sharing material online and most importantly allow for online collaboration and communication between learners. In this respect, the study aimed at evaluating the use of the G Suite for Education integrated in the two EAP courses, eliciting data on the students' views regarding the ease of use of G Suite for Education tools, the difficulties encountered during their use, and their efficiency in the teaching and learning process.

Data was obtained through an online questionnaire, consisting of Likert scale and openended questions, administered to the students at the end of the course. The quantitative data collected was analysed by using the SPSS version 22 programme to run statistical tests. The frequency and percentage of responses were displayed using descriptive statistics and tables. Qualitative data obtained through the use of open-ended questions was restricted; nevertheless, some indicative comments made by the participants are presented in the results section.

\subsection{Participants}

The participants in the study were 68 first-year students attending the two EAP courses aforementioned. The majority were of Cypriot origin, $89.7 \%$, while the rest were Greek, and they all had similar linguistic and sociocultural backgrounds. Details concerning the participants are summarised in Table 3.

Table 3 The participants

\begin{tabular}{lcc}
\hline & $\mathrm{N}=68$ & $\%$ \\
\hline Departments & & \\
DASBFS & 29 & 42.6 \\
DCFS & 39 & 57.4 \\
\hline Sex & & \\
Female & 42 & 61.8 \\
Male & 26 & 38.2 \\
\hline Age & & \\
17-20 & 58 & 85.3 \\
$21-24$ & 7 & 10.3 \\
$25-30$ & 2 & 2.9 \\
\hline
\end{tabular}

\subsection{Results and Discussion}

The first question item on the questionnaire concerned students' level of familiarity with applications offered by Google, before students attended the EAP course. As Figure 1 illustrates, the majority of the participants were already familiar with Google applications, with many students having a personal Gmail account, while a percentage of $13.24 \%$ was not familiar with Google applications at all. 


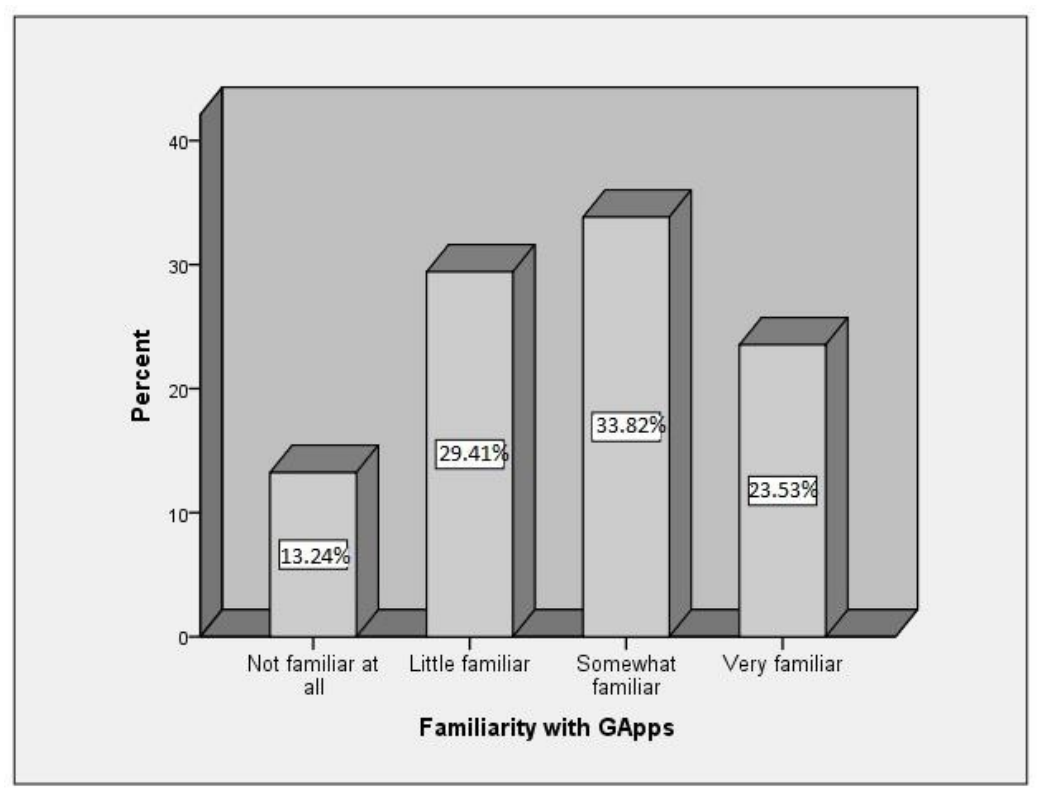

Fig. 1 Students' familiarity with the G Suite for Education

This is an interesting finding, which could justify the reason why eventually the applications that were integrated in the courses were well-accepted and regarded as simple-to-use by the students. Apparently, most of the students were familiar with Google and some of its services, therefore they did not encounter significant challenges while using some of the applications in their EAP classes.

\subsubsection{G Suite for Education ease of use}

The different Google applications that were utilised in the two EAP courses were regarded as very easy or easy to use. As Figure 2 shows, Google Classroom, the Google search engine, Google Drive and Gmail were all considered to be user-friendly.

Nevertheless, in general, there have been some challenges in the use of Google applications recorded in the literature. Roger (2009) supports that there are concerns pertaining to the matters of privacy and security, and despite the fact that Google assures that they take all security measures possible, some educational communities may still regard this as a challenge or rather as a deterrent to integrating Google applications in their classes. 

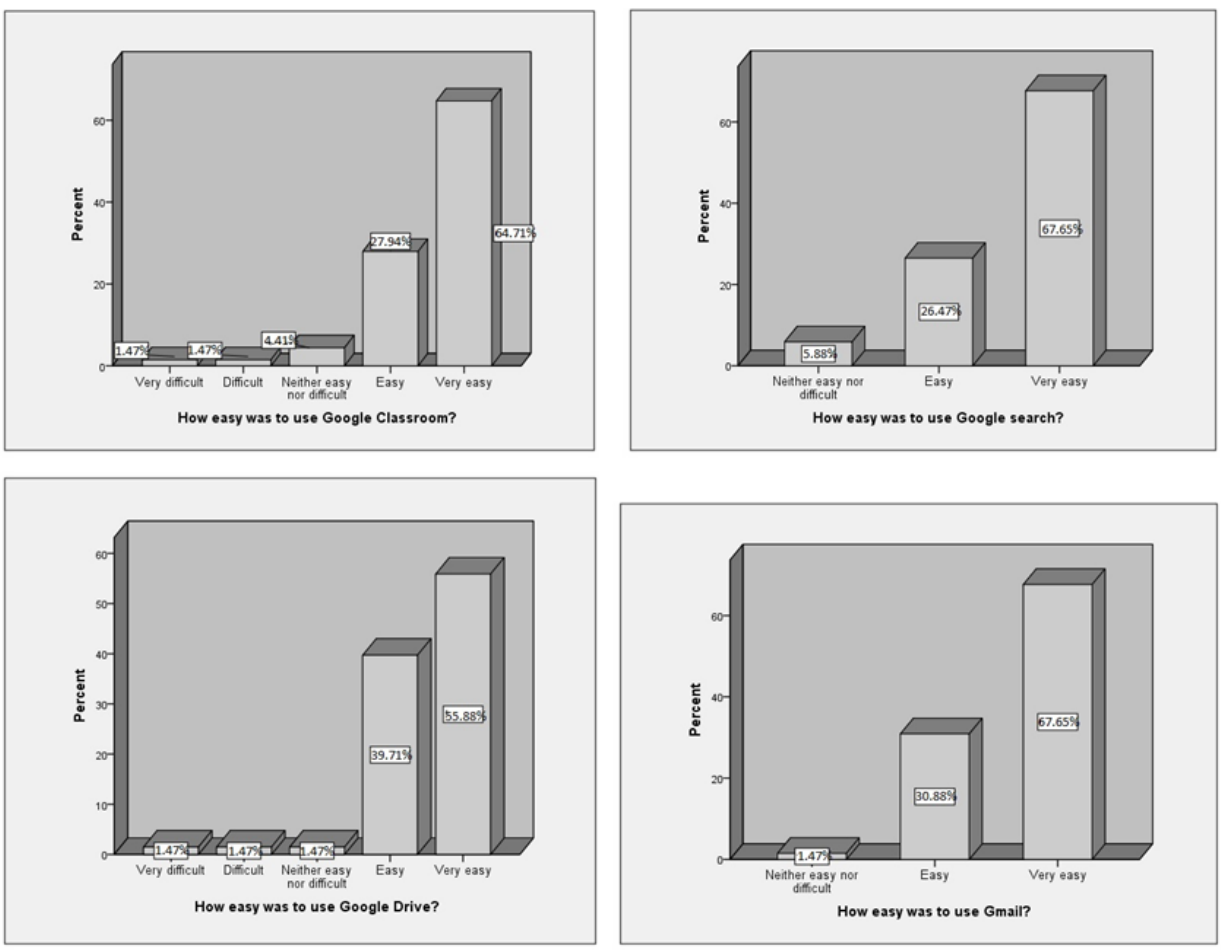

Fig. 2 G Suite for Education ease of use

Some of the challenges that were noted by the students in this study were the following:

- At certain times a student was not sure whether their assignment was actually submitted or not

- Google docs did not include all the features that Word documents have

- It was difficult to get used to the fact that documents are automatically saved on the cloud

- It took some time to get used to the Google Classroom but eventually this was achieved

- Some applications were complicated to use

- A student did not like using a PC in class

These challenges were identified by the course instructor while the course was taking place, and effort was made to deal with them by communicating constantly with the students and providing extra help to the students that requested it.

\subsubsection{Efficiency of the G Suite for Education}

Apart from the difficulties students faced, data was also elicited concerning students' perceptions regarding the efficiency of the G Suite for Education for different teaching and learning processes. Table 4 summarises students' responses. As the Table illustrates, students had very positive perceptions about all the Google tools used (Google Classroom, G Drive, Gmail and Google search). It is worth noting that the majority of students were very positively oriented towards the integration of these tools in their EAP classes. 
Table 4 Efficiency of the G Suite for Education

\begin{tabular}{|c|c|c|c|c|c|}
\hline & Very poor & $\begin{array}{c}\text { Poor } \\
\%\end{array}$ & $\begin{array}{c}\text { Acceptable } \\
\%\end{array}$ & $\begin{array}{c}\text { Good } \\
\%\end{array}$ & Very good \\
\hline \multicolumn{6}{|l|}{ How good is Google Classroom for... } \\
\hline serving as an online platform for the course? & - & - & 2.9 & 35.3 & 61.8 \\
\hline $\begin{array}{l}\text { keeping you informed about the topics and } \\
\text { learning outcomes for each session every week? }\end{array}$ & - & - & 1.5 & 39.7 & 58.8 \\
\hline $\begin{array}{l}\text { providing you with material for the course } \\
\text { (documents, videos, links, course outline, etc.)? }\end{array}$ & - & - & 1.5 & 30.9 & 67.6 \\
\hline $\begin{array}{l}\text { providing you with information about the } \\
\text { instructor? }\end{array}$ & - & - & 8.8 & 26.5 & 64.7 \\
\hline giving you instructions for each task? & - & - & 4.4 & 30.9 & 64.7 \\
\hline uploading assignments? & - & - & 5.9 & 27.9 & 66.2 \\
\hline viewing your grades? & - & - & 8.8 & 32.4 & 58.8 \\
\hline commenting on different topics? & - & - & - & 38.2 & 61.8 \\
\hline $\begin{array}{l}\text { seeing different announcements about the } \\
\text { course? }\end{array}$ & - & - & 11.8 & 38.2 & 50.0 \\
\hline creating a feeling of belonging to a community? & - & - & 7.4 & 38.2 & 54.4 \\
\hline \multicolumn{6}{|l|}{ How good is Google Drive for... } \\
\hline writing notes/ answers to tasks for each class? & - & - & 4.4 & 22.1 & 73.5 \\
\hline creating assignments? & - & - & 2.9 & 38.2 & 58.8 \\
\hline $\begin{array}{l}\text { organising your files and keeping records of } \\
\text { classes/ storing files? }\end{array}$ & - & - & 8.8 & 29.4 & 61.8 \\
\hline collaborating with classmates? & - & - & 7.4 & 27.9 & 64.7 \\
\hline sharing material? & - & - & 8.8 & 30.9 & 60.3 \\
\hline \multicolumn{6}{|l|}{ How good is Gmail for... } \\
\hline communicating with the instructor? & - & - & 4.4 & 33.8 & 61.8 \\
\hline communicating with classmates? & - & - & 10.3 & 36.8 & 52.9 \\
\hline receiving feedback on the assignments? & - & - & 5.9 & 38.2 & 55.9 \\
\hline \multicolumn{6}{|l|}{ How good is Google search for... } \\
\hline finding information on different topics? & - & - & 4.4 & 16.2 & 79.4 \\
\hline explaining unknown vocabulary? & - & 2.9 & 8.8 & 36.8 & 51.5 \\
\hline
\end{tabular}

These results were complemented by the students' comments on the elements that they regarded as the most enjoyable during the course. More specifically, students stated that they mostly enjoyed sharing their opinions and views on Google Classroom using the "Comment" feature on Google Classroom and sharing Google Docs on Google Drive and collaboratively working on them. They considered this extremely helpful, not only for their EAP class, but for other classes too; therefore, many of them admitted that they used the Google account supplied to them by the CUT LC for other subjects as well. Among the things that they enjoyed, they also listed the Google Drive feature of everything being automatically stored on the cloud without the need of carrying any storage devices. In addition, students referred to Google Classroom's affordance of keeping all the material and assignments organised chronologically and thematically, asserting how wellorganised the material was and how easy it was to find it. Another student stressed the importance of the fact that Google and its applications were accessible on mobile devices. Generally, they highlighted the fact that communication was encouraged, and the lesson was more exciting and pleasant with the use of this kind of technology. 
Here are some of the comments they made:

'Google Apps not only helped me in my English lesson, but also in other lessons. I have made team assignments with the help of Google Docs'.

'I enjoyed communication the most. It was more exciting and new using google docs for the lesson rather than just working with books'.

These findings were more or less similar to Lindh, Nolin, and Hedvall's (2016) findings that focused on the implications of affordances identified in the educational applications offered by Google among staff members of a Swedish school organisation. The merits of the Google Suite were also praised by Herrick (2009), who described the migration of Colorado State University to the G Suite for Education, and also by Railean (2012), who discussed the integration of the $G$ Suite in a learner-centered K-12 educational environment. The present study and the studies cited agree that the G Suite for Education seems to encourage communication among users, enact discussion, facilitate the provision of feedback and reflection and promote sharing and collaboration, which are very basic in social constructivist approaches to learning.

Generally, students appeared to have recognised the value of using the G Suite for Education since their evaluation of the whole experience of using it was very positive with the majority of the students characterising this experience as very good (Figure 3 ). What is more, when they were requested to indicate whether they wished to use the same tools in the future or not, $89.7 \%$ responded positively, while $8.8 \%$ did not provide a response.

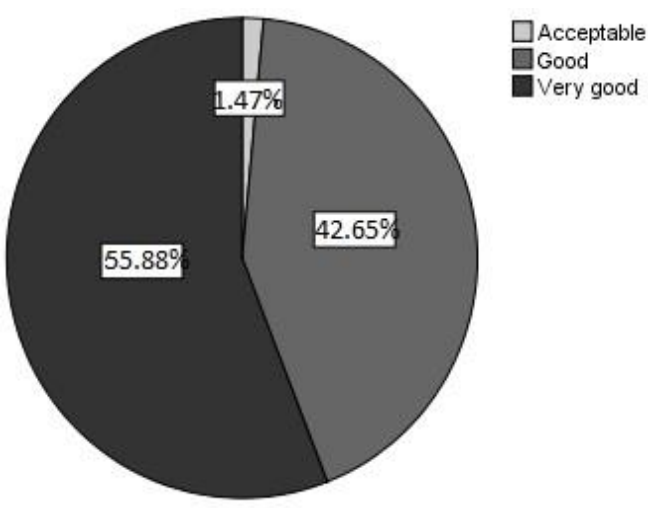

Fig. 3 Evaluation of the experience using the G Suite for Education

Some of the final comments of the students were characteristic of how well the tools were perceived in the two EAP courses:

'Firstly when I was told about google classroom and these tools, I was a little bit cautious because I prefer the traditional method of study, I mean using paper and a pen. It took me a couple of weeks to feel comfortable with that, but now I think that it is a successful way of learning'.

'It was an awesome new experience which led to amazing results and a better communication between the student and the teacher'. 


\section{CONCLUSION}

As the popularity of cloud computing is developing, its potential in education is emerging as well. Cloud services have found their way to different educational environments and even though research in the use of cloud technologies in education is young, more and more studies focusing on the integration of such technologies appear in the literature. Cloud computing has also started invading the area of ESP and all of its branches, i.e. EAP, ESAP (English for Specific Academic Purposes), etc. Yet research in this area is still extremely limited.

The G Suite for Education is one of the most widespread cloud services worldwide with Google being a colossal giant and leader in its field. Despite any difficulties users might experience, its tools are very well-received by both students and teachers, and as it appears in most of the research studies published, they seem to be producing very good results in terms of supporting and enhancing the learning and teaching experience.

Being an action research study, the present study has certain limitations, the most important of which is that results cannot be easily generalised, since the study was conducted in a restricted context for a short period of time. However, the study is ongoing and data on the use of the G Suite for Education in these two courses at the CUT LC are still being collected for the purposes of continuous evaluation and improvement of the courses. Moreover, the study does not investigate the students' perceptions on the impact of the suite on their acquisition of the language. This is an aspect that could be examined in the future.

Despite its limitations, the study may yield some insights regarding future endeavours to integrate the G Suite for Education in ESP courses. The potential of the suite is demonstrated and its many affordances are portrayed in the study. The most significant of all these affordances is the opportunity for collaboration and communication among students, allowing for social constructivist approaches to be followed.

Research in the use of cloud computing in ESP is still in its infancy stage and a lot remains to be investigated. Future research in the field could concentrate on investigating the long-term results from the integration of cloud technologies such as the G Suite for Education in the educational process. It could also focus on examining in greater detail the cognitive reasons behind the success of these tools, which will reveal the way for the creation of more advanced technologies that will promote learning.

\section{REFERENCES}

Blake, Robert J. 2013. Brave New Digital Classroom: Technology and Foreign Language Learning (2nd ed.). Washington DC: Georgetown University Press.

Bloch, Joel. 2013. "Technology and ESP." In The Handbook of English for Specific Purposes, edited by Brian Paltridge and Sue Starfield, 385-401. Chichester: Wiley Blackwell.

Dillon, Tharam, Chen $\mathrm{Wu}$, and Elizabeth Chang. 2010. "Cloud Computing: Issues and Challenges." 2010 24th IEEE International Conference on Advanced Information Networking and Applications, 27-33. doi:10.1109/AINA.2010.187.

Ercan, Tuncay. 2010. "Effective Use of Cloud Computing in Educational Institutions." Procedia - Social and Behavioral Sciences 2 (2): 938-42. doi:10.1016/j.sbspro. 2010.03.130. 
Esteban, Soraya García, and Cristina Tejedor Martínez. 2014. "Critical reflections on teaching ESP through constructivist, communicative and collaborative technological integrated procedures." Procedia Social and Behavioral Sciences 141, 342-346.

Fenton, William. 2017. "Google Classroom Could Bridge a Gap in Online Learning." PC Magazine. https://www.pcmag.com/commentary/354491/google-classroom-couldbridge-a-gap-in-online-learning

Google. n.d. "Spark Learning with G Suite for Education." Accessed April 26, 2018. https://edu.google.com/k-12-solutions/g-suite/?modal_active=none.

González-Martínez, José A., Miguel L. Bote-Lorenzo, Eduardo Gómez-Sánchez, and Rafael Cano-Parra. 2015. "Cloud Computing and Education: A State-of-the-Art Survey." Computers and Education 80: 132-51. doi:10.1016/j.compedu.2014.08.017.

Herrick, Dan R. 2009. "Google This! Using Google Apps for Collaboration and Productivity." Proceedings of the 37th Annual ACM SIGUCCS Fall Conference, 55-64.

Kennedy, Claire, and Miceli Tiziana. 2013. "In piazza online: Exploring the use of wikis with beginner foreign language learners.” Computer Assisted Language Learning 26, 389-411.

Kessler, Greg, Dawn Bikowski, and Jordan Boggs. 2012. "Collaborative writing among second language learners in academic web-based projects." Language Learning \& Technology, 16 (1), 91-109.

Kop, Rita, and Adrian Hill. 2008. "Connectivism: Learning theory of the future or vestige of the past?" The International Review of Research in Open and Distance Learning, 9, no. 3. Accessed June 20, 2018. http://www.irrodl.org/index.php/irrodl/article/ viewArticle/523/1103

Lakshminarayanan, Ramkumar, Binod Kumar, and Marappan Raju. 2013. "Cloud Computing Benefits for Educational Institutions." In Second International Conference of the Omani Society for Educational Technology, 8: 104-12. http://arxiv.org/ftp/arxiv/papers/1305/1305.2616.pdf.

Lindh, Maria, Jan Nolin, and Karen Nowé Hedvall. 2016. "Pupils in the Clouds: Implementation of Google Apps for Education." First Monday. 21 (4) doi:10.5210/fm.v21i4.6185.

Liu, Sarah Hsueh-Jui, and Yu-Ju Lan. 2016. Social Constructivist Approach to WebBased EFL Learning: Collaboration, Motivation, and Perception on the Use of Google Docs. Educational Technology \& Society 19 (1), 171-186.

Mell, Peter, and Tim Grance. 2009. "The NIST Definition of Cloud Computing." https://www.nist.gov/sites/default/files/documents/itl/cloud/cloud-def-v15.pdf.

Railean, Elena. 2012. "Google Apps for Education - a Powerful Solution for Global Scientific Classrooms with Learner Centred Environment." International Journal of Computer Science Research and Application 2 (2), 19-27. www.ijcsra.org.

Roberts, Jon. 1998. Language Teacher Education. London: Arnold.

Roger, Nevin. 2009. "Supporting 21st Century Learning Through Google Apps." Teacher Librarian, 35-38.

Siemens, George. 2005. "Connectivism: A Learning Theory for the Digital Age." International Journal of Instructional Technology \& Distance Learning 2 (1). http://www.itdl.org/journal/jan_05/article01.htm

Sultan, Nabil. 2010. “Cloud Computing for Education: A New Dawn?” International Journal of Information Management 30 (2): 109-16. doi:10.1016/j.ijinfomgt.2009.09.004. 
Vygotsky, Lev, Semyonovich. 1978. Mind in Society: The Development of Higher Psychological Processes. Cambridge, MA: Harvard University Press.

Warschauer, Mark. 1996. "Comparing face-to-face and electronic discussion in the second language classroom." CALICO Journal 13 (2), 7-26.

Yilmaz, Yucel. 2011. "Task effects on focus on form in synchronous computer-mediated communication.” The Modern Language Journal 95: 115-132. 